\title{
Joint Letter to President Bush Urges Increased Federal Support for Scientific Research
}

Throughout 2002, Materials Research Society officers and volunteers joined with the leaders of other societies to engage elected officials in Congress about the support of scientific research. One of the outcomes of this effort was that Congress authorized a 2003 spending plan for the National Science Foundation that was significantly larger than the original budget proposal from the White House, and provided for steadily increasing budgets over a five-year period. This was eventually signed into law by President Bush.
In order to influence the 2004 science budget, MRS and several other scientific societies have again joined together, but this time they started one step further back in the budget-making process. The society presidents wrote to President Bush in January about the need to fund scientific research in order to influence the White House's "opening bid" rather than responding to it after the fact in Congress. The text of the letter follows.
January 3, 2003

The President

The White House

1600 Pennsylvania Avenue

Washington, DC 20500

\section{Dear Mr. President:}

We write to you as leaders of organizations representing more than 1.5 million scientists and engineers throughout the United States to express our concern about diminishing federal budgets for many portions of the R\&D portfolio. We thank you for signing the National Science Foundation Research Act and the commitment it carries with it, and we commend you on your support of the National Institutes of Health. However, we are troubled that many areas of research are being left behind at a time when the sciences have become increasingly interdependent.

Following the November 5th election, you identified national security and job creation as two of your highest policy goals for the coming year. We agree with your goals but note that achieving them will require continued advances in science and technology across disciplines.

The federal government must take steps to strengthen its support of science and engineering research, many aspects of which have suffered significant declines for more than a decade. This very harmful trend has been particularly true for the physical sciences, as your distinguished science and technology advisers point out in PCAST's recent draft report, "Assessing the U.S. R\&D Investment." But it has also been true for many life science subfields outside of biomedicine and for the social sciences. We urge you to adopt the report's recommendations, and we offer you our assistance in implementing its objectives.

- Except for the National Institutes of Health and only very recently the National Science Foundation, most federal agencies have seen their research budgets stagnate or decline in purchasing power for more than a decade. And as the recent RAND report, "Federal Investment in R\&D," notes, the pipeline for the future science and technology workforce is now in jeopardy.

Programs within the Departments of Agriculture, Commerce, Defense, Energy, and the Interior all make critical contributions to the nation's scientific enterprise as do independent agencies such as NASA and NSF. Yet your presidential budgets of the last two years would actually have reduced many of the science and engineering activities of these agencies, once intergovernmental transfers are taken into account. Such reductions would make it difficult to maintain an appropriate balance of funding for individual investigators and large projects, for core programs and initiatives, for universities and national laboratories, and for major equipment or instrumentation and research operations.

As you approach the next budgetary cycle, we call upon you to reverse the decline in science and engineering support that threatens our status as the world's leader in these areas, placing our nation at great future risk. We believe that renewed attention to federal research budgets is central to achieving the economic and military security goals you have identified for your administration and the nation. We strongly urge you to increase support for these science programs in your FY 2004 budget to provide the necessary base for continued technological innovation. We look forward to your administration's timely response.

Respectfully,

Dr. Mary L. Good, Chairman

Alliance for Science and Technology Research in America

Dr. Winfred Phillips, Immediate Past President American Association of Engineering Societies

Dr. Catherine A. Pilachowski, President American Astronomical Society

Dr. Eli M. Pearce, Past President American Chemical Society

Dr. M. Ray Thomasson, President American Geological Institute

Dr. Hyman Bass, President American Mathematical Society

Dr. Richard D. Rosen, President American Meteorological Society

Dr. Myriam Sarachik, President American Physical Society

Dr. Barbara A. Horwitz, President American Physiological Society

Dr. Bettie Sue Masters, President

American Society for Biochemistry and Molecular Biology

Robert G. Hoeft, President

American Society of Agronomy

Thomas L. Jackson, P.E., President American Society of Civil Engineers
Dr. Sally T. Hillsman, Executive Officer American Sociological Association

Dr. Ernest D. Levert, President American Welding Society

Dr. M. Duane Nellis, President Association of American Geographers

Dr. Catherine A. Peters, President

Association of Environmental Engineering and Science Professors

Dr. William S. Smith, Jr, President

Association of Universities for Research in Astronomy

Dr. Suzanne Lenhart, President

Association for Women in Mathematics

Dr. Jill Sideman, President

Association for Women in Science

Dr. Dawn Bonnell, President

AVS: The Science and Technology Society

Dr. Julio Facelli, Chair

Coalition for Academic Scientific Computation

P. Stephen Baenziger, President

Crop Science Society of America

Brian L. Hawkins, President

EDUCAUSE

Dr. Steven L. Teitelbaum, MD, President

Federation of American Societies for

Experimental Biology

Dr. B. Clark Burchfiel, President

Geological Society of America

Dr. Alexander H. King, President, Materials Research Society

Dr. Daryl E. Chubin, Senior Vice President National Action Council for Minorities in Engineering, Inc.

Mr. Delano M. White, National Chairperson National Society of Black Engineers

Dr. Keith Jackson, President

National Society of Black Physicists

Ellen Paul, Executive Director

The Ornithological Council

W. Franklin Gilmore, President Sigma Xi, The Scientific Research Society

Dr. Arthur Getis, President

University Consortium for Geographic Information Science

cc: Mr. Mitchell E. Daniels Dr. John H. Marburger 